\title{
Reassembling International Justice: The Making of 'the Social' in International Criminal Law and Transitional Justice
}

\author{
Kirsten Campbell*
}

\begin{abstract}
$^{1}$
This article examines the most recent shift in ongoing debates concerning the relationship between international criminal law and transitional justice, using the examples of international criminal prosecutions before the International Criminal Tribunal for the former Yugoslavia (ICTY) and transitional justice mechanisms in Bosnia and Herzegovina. It reframes the problematic relationship between the two fields by revisiting the important but underexplored concept of 'the social' that underpins these two very different models of international justice. The article draws on the work of Bruno Latour, who argues that we should study law by analysing how its practices construct 'the social.' Building on this approach, the article shows how international criminal law and transitional justice offer different ways of reassembling social relationships after conflict. While transitional justice seeks to reassemble a society in conflict through 'justice' processes, international criminal law seeks to make social ties through 'law.' The current shift in justice discourses reveals that what is ultimately at stake in these debates is the fundamental question of how international justice can reassemble 'the social' in more just forms after conflict.
\end{abstract}

Keywords: international justice, Bosnia and Herzegovina, International Criminal Tribunal for the former Yugoslavia, Bruno Latour, postconflict reconstruction

In June 2012, the International Criminal Court (ICC), the first permanent international criminal court, handed down its first judgement. With this judgement, international criminal law has now established a crucial role in transitional contexts. However, the impending closure of the ad hoc International Tribunals for the former Yugoslavia (ICTY) and Rwanda (ICTR) also indicates its evolving role in postconflict peace. Once again, international justice discourses are in

* Senior Lecturer, Department of Sociology, Goldsmiths, University of London, UK. Email: k.campbell@gold.ac.uk

1 I would like to thank Suki Ali, David Bausor, David Oswell, Bev Skeggs and the IJTJ reviewers and editors for their helpful comments on earlier versions of this article. I would also like to acknowledge the support of the European Research Council for this research, as part of the Gender of Justice project (Grant No. 313626). 
transition. $^{2}$ I argue that these ongoing shifts in international justice reveal the uneasy relationship between international criminal law and transitional justice.

To reframe this relationship, it is necessary to reconsider the problematic but unproblematized concept of 'the social' that underpins these different models of international justice. To do this, I draw on the work of actor-network theorist Bruno Latour. Actor-network theory (ANT) offers a distinctively new approach to the study of how legal practices construct 'the social.' In particular, Latour's study of law analyses how its particular practices assemble 'society.' Using the example of the ICTY's prosecutions and of transitional justice mechanisms in Bosnia and Herzegovina, I develop an account of international justice as practices of association. I examine how international criminal law and transitional justice offer two very different ways of reassembling social associations during and after conflict. Building on this approach, I argue that what is ultimately at stake in these shifts in justice discourses is how law can reassemble 'the social' in more just forms.

\section{International Justice Discourses in Transition}

The 2004 publication of the UN's report on transitional justice marked the emergence of a new set of 'justice discourses' that identified international criminal and transitional justice as central to conflict resolution and reconstruction. ${ }^{3}$ The relationship between these two key forms of international justice, however, was both uncertain and uneasy. A decade later, debates concerning the role of international criminal law in transitional contexts continue to shape the fields of international criminal law and transitional justice. ${ }^{4}$ However, they also continue to be in transition.

In the field of international criminal law, these debates now centre upon the past 'failure' of the ad hoc Tribunals and the future 'promise' of the ICC for transitional justice. ${ }^{5}$ The increasingly common view is that the Tribunals have been too 'costly, inefficient, and ineffective' in bringing justice to postconflict societies. ${ }^{6}$ In contrast to these 'failed' experiments, the ICC is seen as exemplifying the future promise of international criminal law for transitional justice. ${ }^{7}$ While some international lawyers caution against unrealistic aspirations, the

2 Christine Bell, Colm Campbell and Fionnuala Ní Aoláin, 'Justice Discourses in Transition,' Social and Legal Studies 13(3) (2004): 305-328.

3 'Report of the Secretary-General on the Rule of Law and Transitional Justice in Conflict and Post-Conflict Societies,' UN Doc. S/2004/616 (2004) (hereinafter 'UN TJ Report 2004'); Bell et al., supra n 2 .

4 United Nations, Guidance Note of the Secretary-General: United Nations Approach to Transitional Justice (March 2010).

5 Carsten Stahn, 'Between "Faith" and "Facts": By What Standards Should We Assess International Criminal Justice?' Leiden Journal of International Law 25(2) (2012): 251-282.

6 Ralph Zacklin, 'The Failings of Ad Hoc International Tribunals,' Journal of International Criminal Justice 2(2) (2004): 544.

7 Ruti G. Teitel, 'Transitional Justice Genealogy,' Harvard Human Rights Journal 16 (2003): 69-94. 
predominant response has been 'enthusiasm' resting on 'narratives' of the triumph of the rule of law and the end of impunity for the crimes of war. ${ }^{8}$

While the symbolic function of the ICC in punishing international crimes is seemingly clear, its role in conflict prevention and reconstruction has been more contentious. Nevertheless, international criminal law is generally seen as providing the legal framework for transitional justice, which sets out international legal substantive and procedural norms for the prosecution of international crimes at the national and international levels. ${ }^{9}$ The ICC is seen as the key enforcement mechanism for these norms. Accordingly, it is typically attributed with the transitional functions of determining guilt and punishing crimes, ensuring international and national compliance with these norms and restoring international peace and security. ${ }^{10}$

In contrast, similar debates in the field of transitional justice centre upon the relationship between international criminal law and national transitional justice. These arguments focus upon whether international criminal law should form part of broader integrated national programmes of transitional justice (and, if so, how and in what form). This 'new landscape of transitional justice' emphasizes the importance of developing a wider array of transitional justice mechanisms and processes for postconflict social reconstruction. ${ }^{11}$ In this approach, transitional justice strategies should not involve the imposition of a 'one size fits all' model of international criminal law. For this reason, whether (and how) to integrate international criminal law into national and regional transitional justice programmes becomes the central issue.

Against ideas of 'international criminal law' externally imposed by the international community, 'transitional justice has itself undergone a shift towards the local.' ${ }^{12}$ This broader shift situates international criminal law in the context of local legal cultures and of national needs and capacities, emphasizing its relationship to other forms of local justice, as well as to national legal systems. ${ }^{13}$ What is contentious is the nature of that relationship. The argument predominantly turns on the question of how to reconcile 'global norms with local agency'

8 Frédéric Mégret, 'Three Dangers for the International Criminal Court,' Finnish Yearbook of International Law 12 (2001): 195-247.

9 See, Kai Ambos, 'The Legal Framework of Transitional Justice,' and Christine Bell, 'The "New Law" of Transitional Justice,' in Building a Future on Peace and Justice, ed. Kai Ambos, Judith Large and Marieke Wierda (Berlin: Springer, 2009).

10 Florian Jessberger and Julia Geneuss, 'The Many Faces of the International Criminal Court,' Journal of International Criminal Justice 10(5) (2012): 1081-1094.

11 Naomi Roht-Arriaza, 'The New Landscape of Transitional Justice,' in Transitional Justice in the Twenty-First Century, ed. Naomi Roht-Arriaza and Javier Mariezcurrena (Cambridge: Cambridge University Press, 2006).

12 Rosalind Shaw and Lars Waldorf, 'Introduction: Localising Transitional Justice,' in Localizing Transitional Justice: Interventions and Priorities after Mass Violence, ed. Rosalind Shaw and Lars Waldorf, with Pierre Hazan (Stanford, CA: Stanford University Press, 2010), 4.

13 Kieran McEvoy and Lorna McGregor, eds., Transitional Justice from Below: Grassroots Activism and the Struggle for Change (Oxford: Hart, 2008). 
and processes. ${ }^{14}$ Broader debates concerning the aims of transitional justice also shape these ideas about the use of international criminal law in national transitional processes. At issue is whether the aim of transitional justice is to end conflict and move to a stable and peaceful society (a 'liberal' peacebuilding project) or to address the 'roots of violence' and thereby transform postconflict societies (a project of social transformation). ${ }^{15}$

These debates reveal an important and necessary transition in international justice discourses, which appear increasingly to attribute limited functions to international criminal law and to give a wider role to national transitional justice processes in conflict resolution and reconstruction. ${ }^{16}$ The impending closure of the ICTY and the 'return of the ownership of the justice process to the States in the region ${ }^{17}$ would seem to exemplify these 'lessons learnt' about the role of international criminal law in transition. However, if we take the ICTY as a contemporary exemplar of such transitions in international justice discourses, it becomes possible to see that the shifts also congeal three fundamental and problematic positions in the two fields.

The first problematic position is that international criminal law offers transitional justice a legal framework and an enforcement mechanism. ${ }^{18}$ However, the ICTY did not criminalize the 'large-scale past abuses' or 'human rights violations' that transitional justice initiatives commonly describe as their central normative concerns. ${ }^{19}$ Instead, the ICTY applied the substantive legal rules of customary international humanitarian law, which only criminalizes war crimes, genocide and crimes against humanity. Moreover, the ICTY was established because of the absence of appropriate domestic and international courts and applied customary humanitarian law because these were the only rules beyond doubt binding on all states. ${ }^{20}$ Accordingly, international criminal law does not necessarily provide transitional justice with truly universal norms or enforce global sanctions for their breach.

The second problematic position counterposes international criminal law to national transitional justice. For example, UN Rule of Law Officer Shelley Inglis has noted that a key 'lesson learnt' from the ICTY is that the Tribunal 'failed' as an international criminal law institution to engage with 'the local national

14 Diane F. Orentlicher, "Settling Accounts" Revisited: Reconciling Global Norms with Local Agency,' International Journal of Transitional Justice 1(1) (2007): 10-22.

15 Lisa J. Laplante, 'Transitional Justice and Peace Building: Diagnosing and Addressing the Socioeconomic Roots of Violence through a Human Rights Framework,' International Journal of Transitional Justice 2(3) (2008): 331-355; Lars Waldorf, 'Anticipating the Past: Transitional Justice and Socio-Economic Wrongs,' Social and Legal Studies 21(2) (2012): 171-186.

16 'Report of the Secretary-General on the Rule of Law and Transitional Justice in Conflict and Post-Conflict Societies,' UN Doc. S/2011/634 (2011).

17 Ibid., 22.

18 Luis Moreno Ocampo, 'Building a Future on Peace and Justice,' in Building a Future on Peace and Justice, ed. Kai Ambos, Judith Large and Marieke Wierda (Berlin: Springer, 2009).

19 UN TJ Report 2004, supra n 3.

20 'Report of the Secretary-General Pursuant to Paragraph 2 of Security Council Resolution 808,' UN Doc. S/25704 (April 1993). 
perspective. ${ }^{21}$ However, the ICTY also revealed the problematic nature of such ideas of the international and the national. For example, there is no single 'local national perspective' upon the ICTY. Instead, national 'successor states,' as well as local 'ethnic communities' between and within these states, have divergent notions regarding what transitional justice should be. As Chandra Lekha Sriram describes, 'processes of post-conflict justice are frequent sites of hybridity, in which the interaction of local, national, and international actors shape decisions about accountability in ways that evolve over time. ${ }^{22}$ These range from the impact of European Union accession upon successor states to the current funding crisis within the UN. For this reason, to counterpose international criminal justice to national transitional justice does not capture the complex role of international justice in postconflict societies.

The third problematic position is that the transitional role of international criminal law is to change an unjust society by, for example, establishing an authoritative historical record or condemning criminal conduct. ${ }^{23}$ It is unclear, however, whether it is the nation, the state or 'international society' that is in transition. For example, in the case of the former Yugoslavia, it is all three. The political, legal and social entity of 'Yugoslavia' no longer existed. Moreover, the ICTY was established to reconstruct the 'peace and security' of the international society of states, rather than that of the Yugoslav state or society. ${ }^{24}$ This elision raises, in turn, 'more fundamental questions about what exactly transitional justice is transiting "from" and "to." 25 'Transitional justice' implies a shift from an unjust society (war, authoritarian regimes) to a just society (peace, democracy). However, there are the more fundamental questions concerning the nature of justice that these ideas of transition presume, and which shape the transitional role of international criminal law. The ICTY shows the difficulty of answering this axiological problem. For example, it offers different (and sometimes conflicting) models of justice that range from the classical juridical ideas of procedure and punishment to the more recent transitional aims of social reconciliation and reconstruction. ${ }^{26}$ What counts as justice in transition is never simply 'given' or 'evident.' Instead, it reflects changing values and societies. For these reasons, this position does not adequately address the complicated role of international criminal law in conflict resolution and reconstruction.

21 Shelley Inglis, 'UN Capacity Building: Basing Efforts on Nationally Assessed Goals, Policies and Needs,' in Assessing the Legacy of the ICTY, ed. Richard H. Steinberg (Leiden: Martinus Nijhoff Publishers, 2011), 155.

22 Chandra Lekha Sriram, 'Post-Conflict Justice and Hybridity in Peacebuilding: Resistance or Cooptation?' in Hybrid Forms of Peace: From Everyday Agency to Post-Liberalism, ed. Oliver P. Richmond and Audra Mitchell (London: Palgrave Macmillan, 2011), 58.

${ }^{23}$ UN TJ Report 2004, supra $n 3$.

${ }^{24}$ UN Security Council Resolution 827 of 1992.

25 Christine Bell and Catherine O'Rourke, 'Does Feminism Need a Theory of Transitional Justice? An Introductory Essay,' International Journal of Transitional Justice 1(1) (2007): 23-44.

${ }^{26}$ Kirsten Campbell, 'The Trauma of Justice: Sexual Violence, Crimes Against Humanity and the International Criminal Tribunal for the Former Yugoslavia,' Social and Legal Studies 13(3) (2004): $329-350$. 
The ongoing transitions in international justice discourses congeal these three problematic positions concerning the relationship between international criminal law and transitional justice. Accordingly, the positions operate as an obstacle to reconfiguring this relationship in more productive ways. In order to build a better account of the role of international criminal law in conflict and postconflict transitions, it is necessary to develop another theoretical strategy.

\section{Reassembling 'the Social' in International Justice}

\section{Making 'the Social' in the Practice of Law}

To reframe the relationship between international criminal law and transitional justice, I examine a fourth fundamental concept that is usually taken for granted in these international justice discourses. This is the concept of 'the social.' Ideas of social action and association are central to these discourses because they portray international criminal justice and transitional justice as aiming to regulate forms of violence, which is a fundamentally social activity, as well as to change societies in conflict, similarly a fundamentally social aim. As Ruti Teitel points out, transitional criminal justice attempts to change not only individual social actors but also their broader society. ${ }^{27}$

While 'the social' is therefore central to these international justice discourses, it remains largely unexamined in the field. ${ }^{28}$ An exception to this is a group of researchers working within the Marxist or Durkheimian traditions at the intersection of the fields of transitional justice and international criminal law. ${ }^{29}$ However, the use of these traditions in international justice discourses too often assumes a social totality, whether having existed in the past or coming into existence in the future. ${ }^{30}$ These approaches can mask the difficulty of capturing the role of international criminal justice in transitional contexts, in which mass crimes were intended to destroy the social collective, and criminal law attempts to remake it. ${ }^{31}$

I turn to another tradition in social theory, that of ANT, and in particular the work of Latour. Latour offers what he calls the 'sociology of associations.' 32 This social theory does not assume that law and society are given phenomena that then act upon each other, but rather asks how actions and associations operate to make 'the legal' and 'the social.' Latour sets out his theory of law in The Making of

27 Ruti G. Teitel, Transitional Justice (Oxford: Oxford University Press, 2001).

28 Stephen Parmentier, 'The Missing Link: Criminological Perspectives on Dealing with the Past and Transitional Justice,' in What Is Criminology?, ed. Mary Bosworth and Carolyn Hoyle (Oxford: Oxford University Press, 2011).

29 These include Mark Drumbl, Mark Osiel, Robert Fine, David Hirsh and John Hagan and Ron Levi.

30 Bruno Latour, Reassembling the Social: An Introduction to Actor-Network-Theory (Oxford: Oxford University Press, 2007).

31 Mark J. Osiel, Mass Atrocity, Collective Memory, and the Law (Brunswick, NJ: Transaction Publishers, 1997).

32 Latour, supra n 30. Latour emphasizes that his work on law is not conventional ANT but a study of reassembling the social. Paolo Landri and Bruno Latour, 'Introducing "La Fabrique du Droit," Technoscienza 2(2) (2011): 55-67. 
Law, a detailed ethnographic study of legal practices in the French administrative court. ${ }^{33}$ While his work has not been the subject of detailed consideration in the international criminal law and transitional justice fields, it has become increasingly influential in international legal research. It has been taken up as part of the 'new legal realism,' and the transnational ethnographic study of legal practices in transitional justice is seen as a particularly promising strand of this approach. ${ }^{34}$ Transitional justice scholarship might find this ANT approach most immediately sympathetic. However, as Andrew Barry cautions, the field of ANT cannot simply be applied to an existing disciplinary field, instead requiring a 'translation' between the fields that unsettles both. ${ }^{35}$ In this case, that unsettling involves building an ANT account of international justice, which can reveal another approach to understanding the role of international criminal justice in transitional contexts.

Latour insists that our analysis should begin not with 'the social' as the basis for explaining the relationship between law and society, but rather with how 'the social' is made and remade through networks of association. ${ }^{36}$ This idea of networks will resonate with that of transnational advocacy networks in the field of human rights. ${ }^{37}$ However, the aim of an ANT approach is not to describe the network as an already existing social structure. It aims to understand how this network is made through the building of connections between persons and things. Accordingly, the Latourian model of law shifts from using Marxist and Durkheimian sociologies, with their emphasis upon the social, structure and subject, to the sociology of Gabriel Tarde, with its emphasis upon process, movement and association. ${ }^{38}$ It seeks to move away from these established traditions in sociolegal research 'through which "society was treated as an existing and tangible domain, allowed from a neat division of "law" from "society." ,39 This neat division produces what Teitel describes as the central conceptual problem of any account of international criminal law and transitional justice. This is how to account for the transitional paradox that law is part of both social reproduction and transformation. ${ }^{40}$

\footnotetext{
33 Bruno Latour, The Making of Law: An Ethnography of the Conseil d'Etat (London: Polity, 2010).

34 Sally Engle Merry, 'New Legal Realism and the Ethnography of Transnational Law,' Law and Social Inquiry 31(4) (2006): 975-996.

35 Andrew Barry, 'The Translation Zone: Between Actor-Network Theory and International Relations,' Millennium 41(3) (2013): 413-429.

36 Latour, supra n 30.

37 Thomas Risse and Kathryn Sikkink, 'The Socialisation of International Human Rights Norms,' in The Power of Human Rights: International Norms and Domestic Change, ed. Thomas Risse, Stephen Ropp and Kathryn Sikkink (Cambridge: Cambridge University Press, 1999).

38 David Toews, 'The New Tarde: Sociology after the End of the Social Theory,' Theory, Culture and Society 20(5) (2003): 81-98. See also, Latour, supra n 30.

39 Ron Levi and Marianna Valverde, 'Studying Law by Association: Bruno Latour Goes to the Conseil d'Etat,' Law and Social Inquiry 33(3) (2008): 806.

40 Teitel, supra n 27.
} 
Latour offers an alternative model, where

it's not only that law, for instance, is unexplainable by the influence social forces exert over it; and it's not even true to say that law has to explain in turn what society is, since there is no society to be explained. ${ }^{41}$

Latour's 'sociology of associations' describes 'society' not as substance but as the actions (movements, displacements, translations, mediations and so on) that make social connections. ${ }^{42}$ Critically, one can only act by association with others. For Latour, those others are both human and nonhuman entities. ${ }^{43}$ As Latour explains,

in such a view, law, for instance, should not be seen as what should be explained by 'social structure' in addition to its inner logic; on the contrary, its inner logic may explain the features of what makes an association last longer and extend wider. ${ }^{44}$

This approach conceives law as a 'situated, material practice that ties a whole range of heterogeneous phenomena in a certain specific way. ${ }^{24}$ The idea of practice in this context indicates more than the common divide in sociolegal theory between 'law on the books' and 'law in action.' Rather, it derives from the idea of the making of the social world through action. For Latour, this focus upon practice raises the question of what gives certain actions their 'legal' quality.

Latour understands law as a network of heterogeneous associations that build 'the social.' Law is a 'vehicle, a movement of aggregation,' that assembles entities through particular forms of semiotic and material associations. Latour argues that law 'circulate[s] throughout the landscape to associate entities in a legal way. ${ }^{46}$ Law consists of chains of these associations, since 'making these connections, linking up these elements, weaving the social: all this is law itself. ${ }^{\prime 4}$ For this reason, legality is better understood as a process, in which particular practices organize social relations. These practices associate actants, which are both human (lawyers, defendants, witnesses) and things (court buildings, records, material evidence).

For Latour, 'law' describes particular and peculiar kinds of associations, namely those that construct the vinculum juris, the chain or tie of legal obligation or relation. $^{48}$ Law is a specific way of composing associations in particular forms, which are made of relations that assemble 'the social. ${ }^{49} \mathrm{He}$ identifies specific categories of practice as legal, which he describes as 'modes' or 'regimes'

41 Latour, supra n 33 at 239.

42 Latour, supra n 30.

43 Bruno Latour, 'On Interobjectivity,' Mind, Culture, and Activity 3(4) (1996): 228-245.

44 Latour, supra n 30 at 7.

45 Latour, supra $\mathrm{n} 33$ at $\mathrm{x}$.

46 Latour, supra n 30 at 239.

47 Latour, supra n 33 at 261.

48 Ibid.

49 Ibid. 
of practice. These consist of three key sets of legal practices. The first set is the practices of the legal claim, which initiate the legal process. The second consists of the practices of the legal institution. The third consists of practices of legal reasoning, which include legal judgements and statements. These legal chains operate as a flexible series of links that connect actants through legal practices. They fasten to, and secure, claims and decisions. They operate in a social space as a mesh of interlinked chains of legal practices. This mesh is not above 'the social,' but forms a net of support for the social assemblage by holding its elements together. In this way, they work as the reinforcing structure of the assemblage. The mesh spreads through time and space, constituting its networks through chains of associations or relations, which are assembled through legal practices.

\section{The Social Associations of International Justice}

How, then, do international criminal law and transitional justice operate as forms of association that assemble 'the social' in particular ways? This question reframes the current problematic relationship between the two fields. Reconfiguring Latour's account of law, I examine how international criminal law and transitional justice offer distinctive practices that reassemble society during and after conflict in different ways. To build this account, I examine ICTY criminal prosecutions and Bosnian transitional justice mechanisms, as they exemplify the uneasy and uncertain relationship between international criminal law and transitional justice. Equally important, they currently exemplify the most developed forms of the different international justice practices of international criminal justice and transitional justice. However, the ANT approach does not assume the categories of international and national as explanations of different forms of justice. Rather, it asks how different practices make these kinds of social association. Following this approach, I next examine how ICTY cases and Bosnian mechanisms operate as distinctive practices of association that 'assemble' the social in different forms.

\section{International Criminal Law and the Constitution of International Social Bonds}

The ICTY has come to exemplify the unclear and uneasy role of international criminal law in transitional contexts. However, it has also come to exemplify the operation of international criminal law as a form of international justice. While established with limited purpose and jurisdiction, the ICTY is now widely regarded as inaugurating the field of contemporary international criminal law. It has led the development of substantive and procedural law, as well as international criminal institutions, most notably the ICC. ${ }^{50}$ These characteristics

50 Ruti G. Teitel, Humanity's Law (Oxford: Oxford University Press, 2011). 
make its prosecutions ideal for studying how international criminal justice constructs particular forms of 'the social.'

What are the specific practices of the ICTY that assemble a particular form of social association? Following Latour, we can group these practices into four key categories. The first is the set of practices that transform a social dispute into a legal dispute, such that the conflict becomes a matter subject to legal determination. In Latourian terms, these practices articulate controversies (disputes or disagreements) as legal matters of concern (causes or claims). ${ }^{51}$ In the case of the ICTY, this consists of the classification of armed conflict as subject to international criminal regulation. This 'penal law regime' criminalizes serious violations of humanitarian law and imposes individual criminal responsibility for breaches. ${ }^{52}$ This can be a legal question, which concerns whether an applicable body of law exists that prohibits this conduct, such as customary international law or the ICTY Statute. It can also be a factual question, which concerns whether the law criminalizes that particular form of collective violence, as can be seen in the distinct rules governing the conduct of international and internal armed conflict in Articles 2 and 3 of the ICTY Statute. ${ }^{53}$

The second set of practices makes a matter of legal concern into the appropriate form of a legal claim. In Latour's terms, these practices translate the controversy into a legal statement. They connect legal relations with actors and actions. Latour describes how in law 'paths are traced across the world, weaving numerous relations between claimants, legislative acts, decrees and Codes ... They are traversed by "les moyens de droit" (legal arguments). ${ }^{54}$ In the case of the ICTY, these practices transmute persons and things into legal subjects, such as classifying persons as legitimate military targets or hospitals as prohibited civilian objects. They classify actions into categories of criminal conduct, for example in terms of the elements of the crime set out in substantive international criminal law. These practices translate the highly complex networks of persons and things of the armed conflict in the former Yugoslavia into the material facts and legal issues brought before the Tribunal. For example, these practices interweave the Office of the Prosecutor in The Hague, which investigates criminal conduct under the ICTY Statute, and the North Atlantic Treaty Organization-led Stabilization Force arresting accused war criminals in Bosnia, operating under the UN Charter.

The third set of practices is adjudicative. It consists of the trial proceedings that construct 'credible facts' and 'legal norms' and determine the claim. Latour compares laboratory experiments and legal proceedings as processes for constructing facts, pointing to their shared origins in an empiricist common law. ${ }^{55}$

51 Latour, supra n 33.

52 Prosecutor v. Kunarac, Kovac and Vukovic, Cases No. IT-96-23-PT and IT-96-23/1-PT, Judgement, Trial Chamber (22 February 2001), para. 470 (hereinafter 'Kunarac').

53 Guénaël Mettraux, International Crimes and the Ad Hoc Tribunals (Oxford: Oxford University Press, 2005).

54 Latour, supra n 33 at 233.

55 Ibid. 
Because of his focus on administrative hearings, rather than criminal trial proceedings, Latour does not adequately draw out this comparison. However, like the laboratory, the ICTY courtroom is the site of fact and norm construction. The legal proceedings that take place in that courtroom seek to establish the truth of legal claims, just as the scientific experiment aims to establish a scientific claim. These practices range from presentation of witness evidence to the use of legal argument. Each party seeks to establish its legal claim using these practices to enrol human actants, such as witnesses and lawyers, as well as nonhuman actants, such as The Hague court buildings or the ICTY judicial database which transcribes their evidence and argument.

Finally, the fourth set of practices involves judging these claims. As Latour describes, 'a case has to be concluded. ${ }^{56}$ For him, judgement is fundamental to law as a mode of enunciation. ${ }^{57}$ In the case of a criminal court such as the ICTY, these practices of judging conclude the case by determining fact, law, liability and punishment. These range from the use of legal doctrine and reasoning to their inscription in the formal legal text of the judgement. They include practices of determining legal findings, which serve as the axiological foundation of the legal determination of responsibility and punishment. They also involve fact-finding practices, which serve as the epistemic foundation of the legal determination of 'fact.' These practices settle the 'controversy' of the legal claim by passing final judgement upon the claims of the parties to justice before the law.

The example of the ICTY shows how international criminal justice is a set of particular practices that make legal associations. Take, for example, Prosecutor $v$. Kunarac, which the ICTY identifies as a leading sexual violence case. ${ }^{58}$ This case transformed sexual violence committed in the war in the former Yugoslavia into a matter subject to international legal determination. The OTP translated this matter of legal concern into a legal claim, namely, charges of sexual enslavement. The trial proceedings were the site of fact and norm construction, in which each party sought to support the claim, whether by the prosecution's presentation of victim-witnesses at trial or the defence appellant arguments that there was a legal error in the interpretation of the elements of the crime. ${ }^{59}$ Legal judgement determined that these victim-witnesses suffered sexual enslavement and found the accused criminally responsible. ${ }^{60}$ These practices operate both spatially and temporally to assemble entities in new legal relations to each other. The survivors of sexual violence in Foča became witnesses testifying many years later in a courtroom in The Hague and the 'Bosnian Serb' soldiers became legally responsible for their treatment of these 'Muslim' civilians and were sentenced to prison in Norway and Germany. These practices assembled social associations by 'making

56 Ibid., 221.

57 Ibid.

58 International Criminal Tribunal for the former Yugoslavia, 'Landmark Cases,' http://www.icty. org/sid/10314 (accessed 23 October 2013).

59 Kunarac, Judgement, Appeals Chamber, 2002.

60 Kunarac, Judgement, Trial Chamber, 2001. 
these connections, linking up these elements, weaving the social' and working to associate entities in a legal way, as Latour describes. These 'legal' associations connected together to form the chain or tie of legal obligation or relation. ${ }^{61}$ By establishing ties of legal obligation, these practices of international criminal justice assembled 'the social' in law. These chains of legal obligation created new social associations in law, while simultaneously extending those associations across a social space.

In international criminal justice, such chains of legal obligations create new 'international' social associations. They are international rather than domestic obligations because they prosecute acts and actors in a situation of collective violence that is considered to be the subject of international legal regulation. They are also international in the sense that even though the trials take place in the Netherlands, they use international legal norms to define international crimes and conduct proceedings according to international legal standards. ICTY jurisprudence clearly establishes that it applies international legal norms that derive from the positive law and values of the international legal order. It adjudicates breaches of these norms according to accepted practices of evidencing facts as well as conventions of legal argumentation accepted as such within the legal culture of international criminal justice. ${ }^{62}$ In this way, these legal practices create an international form of social association.

International criminal justice, such as that practiced by the ICTY, offers chains of legal obligation that assemble 'the social' in law. It operates as a particular mode of creating 'the social' by using the practices of criminal justice to create the chain of international legal obligation. In international criminal justice, this sociality is assembled in law, but it does not create a new society as such. Rather, the legal chains only create new social associations, and with them chains of legal obligations. As ICTY President Judge Patrick Robinson describes, 'one lesson learnt from our experiences is that the core mandate of an international criminal court that is to investigate, prosecute, and adjudicate grave breaches of international humanitarian law is very clear. ${ }^{63}$ These prosecutions aim to create stable legal associations that assemble 'the social' in law. However, they assemble a minimal form of 'the social,' which only consists of new legal relations. This minimal form of social association only exists insofar as networks of legal practices support it. These chains fasten to, and secure, claims and decisions in the ICTY. However, these new legal associations do not create a social 'totality.' Instead, they create new social ties in a specific legal assemblage.

Because these stable legal associations assemble 'the social' in law, they only carry this assemblage as far as the legal chains extend. For example, the ICTY's

61 Latour, supra n 33.

62 Kirsten Campbell, 'The Making of Global Legal Culture and International Criminal Law,' Leiden Journal of International Law 26(1) (2013): 155-172.

63 Patrick Robinson, 'Creating a Legacy that Supports Sustainable Rule of Law in the Region,' in Assessing the Legacy of the ICTY, ed. Richard H. Steinberg (Leiden: Martinus Nijhoff Publishers, 2011), 23. 
legal chains do not extend to the successor states of Bosnia, Croatia, Serbia or Slovenia, which have created their own legal assemblages of claims, courts and judgements. Moreover, although the ICTY prosecutions enforce international legal norms, they do not necessarily create enforceable legal relations between these states as participants in the international legal order (as the Genocide decision of the International Court of Justice demonstrates). ${ }^{64}$ Where the legal associations of the successor states utilize the practices of international criminal law, such as the application of international customary legal norms developed by the ICTY, the chains of legal obligation become longer. Where they do not, the chains remain short.

The ICTY therefore creates this 'international' form of social association in the 'local' legal space of The Hague. These short chains of legal obligation create minimal social ties. For this reason, international criminal justice constructs a 'small' social assemblage, which it seeks to extend through chains of legal association that are long in time and space. Ultimately, these prosecutions aim to create new social associations in law and to extend these associations to carry those social connections across global space and time because they are constructed as universal legal ties. Nevertheless, they are short chains of association, which create short rather than long networks of people and things. In these prosecutions, the chains do not extend far beyond the legal association of these claims and decisions in the ICTY courtroom.

The transitional challenge is how to extend these ties of responsibility into the former Yugoslavia in particular and to spaces of collective violence in general. To do this requires the invention of supporting legal practices. For example, a key problem for the ICTY has been how to extend its legal chains of obligation, to enrol more actants and to create new forms of association, and so to generate new forms of 'the social' in the 'region.' The ICTY itself puts this problem succinctly:

In view of the international nature of the Tribunal and its physical distance from the communities affected by the crimes under its jurisdiction, a serious outreach effort was undertaken to make justice rendered in the Tribunal's courtrooms seen in its natural constituency - the former Yugoslavia. ${ }^{65}$

The Tribunal sought to remake 'the social' of the former Yugoslavia by constructing new chains of legal obligation that could 'assemble' a postconflict region. These legal chains attempt to build a postconflict sociality. With the ICTY's cases, these chains of legal obligation have been too short and weak to properly reassemble a postconflict society as such. With the impending closure of the ICTY, and the problem of its 'legacy' in the region, the Tribunal is again attempting to extend and sustain the legal chains of obligation it has worked so hard to create. As these chains of international legal obligation are short and this minimal

${ }^{64}$ Case concerning the Application of the Convention on the Prevention and Punishment of the Crime of Genocide (Bosnia and Herzegovina v. Serbia and Montenegro), Judgement (26 February 2007).

65 International Criminal Tribunal for the former Yugoslavia, 'Outreach,' http://www.icty.org/ sections/Outreach (accessed 23 October 2013). 
form of social association operates within a given legal space (in this case, the ICTY), the Tribunal's legal associations require other chains of social associations, created by other actants and actions, to extend across time and space.

\section{Transitional Justice and the Making of the Postconflict Social}

In contrast to the ICTY, Bosnia and Herzegovina is a social space saturated by contemporary transitional justice practices that are a hybrid of international and national elements and of formal and informal processes. As such, postconflict Bosnia exemplifies contemporary transitional justice. Although Bosnia may appear to be a straightforward case of national transitional justice, in actuality international transitional processes created the Bosnian nation-state. These transitional processes operate at international, regional, national and local levels and range from the internationalized tribunal of the War Crimes Chamber (WCC) to civil society initiatives of local victims' associations. ${ }^{66}$ They include formal legal processes, such as ongoing prosecutions in state and cantonal courts, as well as informal justice processes, such as recent initiatives to establish the Women's Court for the Crimes of the former Yugoslavia. ${ }^{67}$ Bosnia thus exemplifies the 'full range' of transitional justice processes and mechanisms described in UN policy.

These transitional practices in Bosnia consist of particular forms of association that seek to reassemble social relationships during and after conflict. However, because Latour's work does not engage with transitional justice as such, it is necessary to develop a new ANT account of what kinds of transitional practices reassemble 'the social.' Rama Mani's classic work can serve as a useful basis for developing this account. She identifies the three categories of legal, rectificatory and distributive justice in postconflict peacebuilding. ${ }^{68}$ However, peacebuilding and transitional justice mechanisms are not equivalent, and it is not possible simply to apply Mani's typology to the transitional context of Bosnia. ${ }^{69}$ Instead, it is necessary to adapt the categories in order to develop a new typology of transitional justice practices as legal, criminal, reparative and transformative.

The first category of transitional practices is legal justice. Following Mani, these practices aim to (re)construct the rule of law. This category includes what Teitel calls administrative and constitutional justice. These 'rule of law' practices include the rebuilding of the legal framework of the state, as well as the legal system itself. $^{70}$ The practices range from international recognition of the postconflict state to the extensive (but problematic) institutional reforms, vetting and

66 See, UN Development Programme in Bosnia and Herzegovina, http://www.undp.ba/index. aspx?PID=7\&RID=772 (accessed 23 October 2013).

67 Adriana Zaharijević, 'On Trial at the Women's Court: Gender Violence, Justice and Citizenship,' Citizenship in Southeast Europe, 19 December 2012, http:/www.citsee.eu/citsee-story/trialwomen\%E2\%80\%99s-court-gender-violence-justice-and-citizenship (accessed 23 October 2013).

68 Rama Mani, Beyond Retribution: Seeking Justice in the Shadows of War (Cambridge: Polity, 2002).

69 Waldorf, supra n 15. Mani acknowledges these ideas need to be developed in the light of empirical practice, and that these justice mechanisms are shaped by their postconflict contexts.

70 Teitel, supra n 27. 
dismissals undertaken in postwar Bosnia. ${ }^{71}$ These practices emerged with the complex process of state recognition during the war in 1992 and the establishment of a postconflict constitution and system of government under international administration under the Dayton Peace Agreement in $1994 .^{72}$ These rule of law practices continue to be integral to the transitional Bosnian state, which is still grappling with constitutional, legal and institutional reform in the context of continuing administration by the Office of the High Representative and future European Union accession. ${ }^{73}$ In Latourian terms, these practices aim to assemble the nation-state as a 'social aggregate,' in which rule of law practices work as a social tie. They associate multiple actants, connecting them in a series of particular and stable associations that build the nation-state. ${ }^{74}$

The second category of transitional practices is criminal justice. Bosnian war crimes have been prosecuted at the international level before the ICTY, at the state level in the WCC after its establishment in 2005 and at the entity and local levels in the cantonal and district courts. ${ }^{75}$ With the impending closure of the ICTY, the prosecution of war crimes will now take place in Bosnia. These crimes are prosecuted as 'international' crimes under the criminal codes of Bosnia and Herzegovina of 2003 and the prewar Socialist Federal Republic of Yugoslavia of 1976 or as 'ordinary' crimes under domestic criminal codes, and are heard before the WCC or before entity and cantonal courts. ${ }^{76}$ These prosecutions are also subject to European human rights norms. ${ }^{77}$ As the example of sexual violence prosecutions shows, these proceedings do not uniformly apply international legal norms to define these crimes, prosecute these crimes according to international legal standards or apply consistent national legal norms across Bosnia. ${ }^{78}$ However, they do apply substantive criminal law, use criminal trial procedure, judge criminal liability and determine penal sanctions across the nation-state.

These Bosnian prosecutions all use particular forms of criminal justice practices. As we have seen in the case of the ICTY prosecutions, they make the

71 Jakob Finci, 'Lustration and Vetting Process in Bosnian and Herzegovina,' in Lustration and Consolidation of Democracy and the Rule of Law in Central and Eastern Europe, ed. Anđelko Milardović and Vladimíra Dvořáková (Zagreb: Political Science Research Centre, 2007).

72 Sumanatra Bose, Bosnia after Dayton: Nationalist Partition and International Intervention (London: Hurst, 2002).

73 See, Timothy Donais, 'Power Politics and the Rule of Law in Post-Dayton Bosnia,' Studies in Social Justice 7(2) (2013): 189-210.

74 Latour, supra n 30.

75 See, Olga Martin-Ortega, 'Prosecuting War Crimes at Home: Lessons from the War Crimes Chamber in the State Court of Bosnia and Herzegovina,' International Criminal Law Review 12(4) (2012): 589-628.

76 Organization for Security and Co-operation in Europe, Delivering Justice in Bosnia and Herzegovina (2011). My thanks to Jasenka Ferizović for clarification of this point.

77 Maktouf and Damjanović v. Bosnia and Herzegovina (application nos. 2312/08 and 34179/08), Grand Chamber, European Court of Human Rights (18 July 2013).

78 For further discussion, see, Gorana Mlinarević, Jakob Čaušević and Jasmina Čaušević, Prosecution of Wartime Sexualized Violence at the Court of Bosnia and Herzegovina (Sarajevo: UN Women, 2012). My thanks to Gorana Mlinarević for drawing my attention to this report and to the European Court of Human Rights decision. See also, TRIAL, The Situation of Women Victims of Rape or Other Forms of Sexual Violence during the War in Bosnia and Herzegovina (May 2011). 
conduct into a matter of legal concern, articulate that matter of concern as a crime, adjudicate those criminal charges through trial proceedings and determine those claims by legal judgement upon criminal culpability and punishment. In Latourian terms, these are practices of legal association. Mani describes such prosecutions for 'gross human rights violations, war crimes and genocide' as 'rectificatory justice.' For her, this broad category of 'processes of reckoning' for direct violence during conflict also includes truth commissions, lustration and memorialization. ${ }^{79}$ However, it is necessary to acknowledge that criminal prosecutions have a distinctive transitional role, as Teitel argues. Departing from Teitel, I suggest this role derives from the specific form of social association in criminal law, rather than any transitional qualities of law as such. ${ }^{80}$ These forms of social association tie together actants through chains of legal obligations of criminal justice.

The third category of transitional justice practices is reparative and includes reparations, memorialization, truth seeking and reconciliation processes. These practices range from the formal restitution of property led by the UN High Commissioner for Refugees and the Office of the High Representative in 1998 to the civil society-led initiative in 2008 to establish a regional Reconciliation Commission (RECOM) and the memorialization policy developed under the Transitional Justice Strategy in 2012, led by the Bosnian state and the UN Development Programme. ${ }^{81}$ These form a distinctive set of nonlegal processes that provide redress for the injustices of violence, which Mani includes in 'rectificatory justice.' I argue, however, that the idea of 'reparative justice' better captures these practices as it does not suggest that they aim to provide redress or reckoning as an end in itself. Rather, it emphasizes their attempts to repair or rebuild social assemblages. It does not imply that these practices aim to restore broken social networks to their previous forms of association, but rather that they aim to reassemble a collective.

The fourth category of transitional practices aims to transform postconflict society by addressing the structural and systemic injustices that caused the conflict. $^{82}$ One example is the Women's Court for the Crimes of the former Yugoslavia. This regional initiative of women's organizations seeks to address the structural shaping of the war and to situate the violence of war in the context of past and present social violence, such as economic and gender violence. ${ }^{83}$

79 Mani, supra n 68 at 87 . In the Bosnian context, lustration is not usually described in terms of reckoning or punishment, but in terms of rule of law issues. For this reason, I include it in the category of legal justice.

80 For this reason, I do not follow Teitel in calling these practices transitional criminal justice. See, Teitel, supra n 27.

81 See, UN Development Programme in Bosnia and Herzegovina, Access to Justice: Facing the Past and Building Confidence for the Future (2009); UN Development Programme in Bosnia and Herzegovina, Looking Forward, Looking Back (2012).

82 Mani, supra n 68.

83 For an overview of this initiative, see, Maja Šoštarić, War Victims and Gender-Sensitive Truth, Justice, Reparations and Nonrecurrence in Bosnia and Herzegovina (Utrecht: Impunity Watch, 2012). 
This new approach links postconflict justice to 'societal transformation' that does not sustain the 'dependence and subordination' that existed prior to conflict or which its violence produces. ${ }^{84}$ While Mani calls this 'distributive justice,' the term 'transformative justice' is more appropriate because it captures how these practices aim to assemble 'the social' in radically new and transformative ways.

These four categories of transitional justice practices use different forms of semiotic and material practices to make new social associations. The first characteristic they share is that they are transitional associations. They aim to assemble entities in new transitional relations to each other. Transitional practices thus intend to build more than legal chains of responsibility; they attempt to make new transitional associations that can serve as the building blocks of a postconflict society. For example, memorialization has been a highly divisive practice in Bosnia that has predominantly taken the form of 'communal' recollection or destruction. ${ }^{85}$ The recent bombing in Mostar of the (Bosniakassociated) Bosnian Army memorial is only one such example. ${ }^{86}$ However, there is currently an attempt to devise transitional practices of memorialization. The BiH TJ Strategy Expert Report characterizes transitional memorialization as a practice of 'truth-telling' that records the historical truth of the conflict in a public space. It claims that 'truth-telling' can operate as a form of reparative justice, which can acknowledge past crimes and hence rebuild social relationships. ${ }^{87}$ Transitional memorialization is seen as an important element of the strategy, which is now developing a pilot project in Brčko District. ${ }^{88}$ When operating as a communal practice, memorialization is seen as solidifying 'ethnic community.' As a transitional justice practice, it aims to transform the social associations of ethnic division into social associations of 'peace.'

The second characteristic of these transitional justice practices is that, unlike international criminal prosecutions, they seek to change society as a whole and build a new postconflict one. To reassemble 'the social' in this way requires a 'full range of processes and mechanisms,' running from criminal prosecutions to oral history projects. These practices seek to do more than change specific communities in a particular place, such as the Brčko memorialization project. Instead, they aim to reassemble a society in conflict as a society in peace, so that this pilot project becomes a model for transitional memorialization across Bosnia.

84 Susan Harris-Rimmer, 'Sexing the Subject of Transitional Justice,' Australian Feminist Law Journal 32 (2010): 123-147.

85 Janine Clark, 'Reconciliation through Remembrance: War Memorials and the Victims of Vukovar,' International Journal of Transitional Justice 7(1) (2012): 116-135.

86 Denis Dzidic, 'Bosnia Officials Condemn War Memorial Blast,' Balkan Insight, 15 January 2013, http://www.balkaninsight.com/en/article/mostar-memorial-attack-condemned (accessed 23 October 2013).

87 UNDP Bosnia, supra n 81.

88 See, UN Development Programme in Bosnia and Herzegovina, 'Consultations on Truth-Telling and Memorialisation in the Brcko District of Bosnia and Herzegovina,' 12 February 2013, http://www.undp.org/content/bosnia_and_herzegovina/en/home/presscenter/articles/2013/02/ $12 /$ consultations-on-truth-telling-and-memorialisation-in-the-brcko-district-of-bosnia-andherzegovina/ (accessed 23 October 2013). 
As such, these practices aim to reassemble 'the social' as a collective whole. Nevertheless, the dominant transitional form of this collectivity is the bounded nation-state. Following Latour, the postconflict nation-state is not a preexisting entity but a collectivity that needs to be made in time and space by enrolling a multiplicity of actants in a multiplicity of networks. All such transitional practices seek to assemble that complex collectivity, the postconflict society. However, their dominant mode of (re)creating the social is to assemble it as a nation-state.

Transitional justice is also a particular mode of creating 'the social.' It uses distinctive practices to create new social associations. However, in contrast to the legal practices of international criminal justice, transitional justice operates to build more than chains of legal association. Rather, it has the ambitious task of building a new postconflict society that explicitly reconstructs former social divisions so as to build a new social collectivity across time and space. In Latourian terms, these transitional chains of social association attempt to make action at a distance possible. They attempt to build the stronger and denser chains of social association necessary to assembling large collectivities. However, as opposed to the universal ties of international legal obligation, the dominant mode of creating 'the social' in these transitional practices is to build comparatively short chains of social association across the bounded time and space of the nation-state.

This mode of social association requires durable and dense chains of transitional practices that are sufficiently strong to build a large social assemblage. To sustain this large collectivity, these new transitional chains of social association must be robust enough to endure across space and time. For example, they will ultimately construct, or not, the connection between the international judge in the Sarajevo court and the Bosnian Serb defendant being tried before him or her. In Latour's terms, these practices build associations of human and nonhuman actants that are essential to the construction of this new transitional assemblage of 'the social. ${ }^{89}$ They attempt to build new chains of social associations, which can be longer or shorter or can be part of wider or smaller networks. The most effective practices assemble a new postconflict sociality by extending these associations and sustaining them through time and space. If international criminal justice is a 'minimum' form of social association, then transitional justice is a 'maximum' form of social assemblage. All four categories of transitional practices attempt to reassemble 'the social' as such in a stable and durable form.

\section{Reassembling International Justice}

The current transition in international justice discourses questions the role of international criminal law in transitional societies. My ANT approach suggests

89 Latour, supra n 30. 
that this question presumes that international criminal law and transitional justice are preexisting entities, rather than examining how they are modes of social association. Instead, pace Latour, the question is how to identify 'the associations that have rendered some state of affairs solid and durable. ${ }^{90}$ Developing this approach, we can see how international criminal law and transitional justice operate as modes of action that make facts, objects, networks and collectives. They create weaker or stronger associations, construct longer or shorter networks and build minimal or maximal forms of postconflict social association. In empirical terms, these practices may fail to assemble new collectives. They may not be able to enrol sufficient human and nonhuman actors and resources. They may build connections to other networks, which then use them to create collective conflict or violence. However, in analytic terms, both international criminal law and transitional justice offer different practices of assembling social associations after conflict, which attempt to make these collectives solid and durable.

These two modes of creating social association use different practices of association, which operate as distinct modes of connection between actants. ${ }^{91}$ International criminal law seeks to make social ties through international criminal justice practices, while transitional justice seeks to reassemble a society in conflict through legal, criminal, reparative and distributive justice practices. These are distinctive practices that produce social associations in minimal and maximal forms. International criminal law assembles 'the social' in law by creating chains of legal obligation. These chains create new legal associations, but not a new collective as such. They are 'short' because they extend only as far as legal practices do. However, international criminal law seeks to extend these chains globally, because its practices construct international legal obligations. In contrast, transitional justice aims to assemble postconflict collectives. These social ties need to be more extensive and denser because transitional justice practices aim to reassemble a large social association, the nation-state. However, they do not have to extend as far as those of international criminal law because they aim to build a limited and bounded social space.

To build more stable and solid postconflict collectives therefore requires linking these two modes of reassembling 'the social.' This involves multiplying and extending connections between the stable but short legal associations of international criminal law and the more unstable but dense ties of transitional justice practices in order to assemble minimal and maximal postconflict collectives. To do this, international criminal justice practices need to be made into longer chains of association and attached to the denser and more extensive ties of transitional justice practices. Transitional justice practices also need to attach to the new international legal obligations and settlement of collective

90 Ibid., 93.

91 Bruno Latour, An Inquiry into Modes of Existence: An Anthropology of the Moderns (Cambridge, MA: Harvard University Press, 2013). 
violence in international criminal justice. In Latour's terms, this involves undertaking the work of enrolling actants and resources that can build networks and so assemble postconflict collectives. ${ }^{92}$

An example of this labour can be seen in the WCC. Like the ICTY, the WCC uses particular practices of international criminal law to make legal associations. These legal chains bring entities into new relations of international legal obligation to each other. So, for example, the WCC operates as a new form of social association. This involves passing new laws defining international crimes, constructing courtrooms to international standards and conducting trial proceedings. These chains of legal association then connect to others, creating networks between judges from the US and witnesses from Foča, from the Sarajevo court to the district and cantonal courts of the Bosnian entities and from the judicial institution to the donor countries of the European Union. The WCC is a hybrid site that assembles a multiplicity of international and national legal and political networks through its social associations. It produces short chains of legal obligation that create 'the social' in law, which it seeks to extend through time and space through the building of legal networks of actors and actions across the Bosnian nation-state.

Therefore, an important strategy in reassembling postconflict collectives is extending these legal chains of social association in transitional space and time. This requires recognizing the hybridity of international criminal justice and connecting this social assemblage to other transitional chains of social association. An important example of this process is the Court Support Network, which aimed to 'integrate the mission of the Court into the wider Bosnian community. ${ }^{93}$ Alex Jeffrey's important study of this network shows that the policy of

building connections between court processes and community groups ... has not only assisted in the process, but has brought new spaces of justice into being through education programmes, transnational connections, and innovative forms political participation. ${ }^{94}$

These 'soft' justice practices (as opposed to the 'hard' justice practices of international criminal law) work to extend the short legal chain of obligation (thereby demonstrating their imbrication, as Jeffrey suggests). These chains of social association can then become longer and attach to wider transitional networks, thus making the chain of legal association denser and more durable in its movement through social space and time. This can sustain these legal chains of obligation so that they can become an integral element of the transitional assembling of new postconflict collectives.

92 See, Bruno Latour, Science in Action: How to Follow Scientists and Engineers through Society (Cambridge, MA: Harvard University Press, 1988).

93 Alex Jeffrey, 'The Political Geographies of Transitional Justice,' Transactions of the Institute of British Geographers 36(3) (2011): 352.

94 Ibid., 349. 
A second important strategy involves connecting transitional practices to international criminal justice practices. The settlement of conflict by international criminal justice practices constitutes certain forms of 'the social' (rather than others) by virtue of the kinds of chains of legal obligations it builds. These are international obligations because they prosecute acts and actors in a situation of collective violence that is considered to be the subject of international legal regulation. They use international legal norms to define these international crimes, and prosecute these crimes according to international legal standards. The importance of these international legal chains of obligation to the assemblage of postconflict collectives is revealed by sexual violence prosecutions in Bosnia. These legal ties can create a new legal subject (the victim as the possessor of the legal right to sexual autonomy) that exists in new legal relations (sexual violence in war as prohibited conduct) to other legal subjects (the perpetrator as the bearer of criminal responsibility). However, the failure to construct these legal obligations across the Bosnian nation-state has entailed that such conduct is not necessarily characterized as an international crime, the victim does not possess the right to sexual autonomy or the perpetrator does not suffer appropriate punishment for the crime. ${ }^{95}$ To address this failure to build postconflict collectives that include these legal associations, it is necessary to connect international criminal justice practices to the legal and criminal justice practices of transitional justice. These minimal social ties of international criminal justice are crucial elements of reassembling collectives that do not simply reproduce the injustices of conflict.

In this mode of making 'the social,' international criminal justice can link to transformative justice practices. For Latour, law is fundamentally conservative, since the legal settlement of disputes sustains (rather than disrupts) the existing order. ${ }^{96}$ However, this is not a necessary condition of such a legal settlement, or its only form. It can also create new matters of concern, claims, adjudication and judgement. This is law at its most inventive. ${ }^{97}$ In this transformative mode of social association, international justice involves the invention of a new settlement for claims of injustice, which can then produce a new chain of legal obligation. This legal chain would construct the connection between claims to injustice and the collectivities that produced them. In this way, law can translate new claims to injustice into legal concerns and inscribe these new injustices into the legal rules symbolizing harms, thereby changing that naming of wrongs. It can construct new credible facts and original epistemic norms for determining a claim. Finally, it can develop new norms of judgement and justice. For this reason, the invention of new forms of legal association in international criminal justice is crucial for inventing new forms of transitional justice.

\footnotetext{
95 See, TRIAL, supra n 78; Amnesty International, 'Whose Justice?' The Women of Bosnia and Herzegovina Are Still Waiting (2009); Organization for Security and Co-operation in Europe Mission to Bosnia and Herzegovina, Delivering Justice in Bosnia and Herzegovina: An Overview of War Crimes Processing from 2005 to 2010 (2011).

96 Latour, supra n 33.

97 Ibid.
} 
Both these strategies require reassembling international justice, with the invention of new practices and new collectives. Some claims and claimants are more persuasive than others because international justice is not flat, neutral or equal. For this reason, it is necessary to undertake

counting in participants and issues who have not managed or are not likely to succeed in articulating their concerns, or whose modes of articulation indicate a politics that is 'imperceptible' within prevalent ways of understanding. ${ }^{98}$

The challenge is to identify how international justice can be invented and remain inventive in transitional contexts so that it can 'count in' claims and participants. This involves a process of creating new justice practices, and hence inventing new forms of association. These innovations have the capacity to create alternative forms of association and novel forms of 'the social' by offering a new settlement of collective violence.

This sociology of legal associations shows how the divergent practices of international criminal justice and transitional justice construct different forms of 'the social.' In international criminal law, the short legal chains of obligation create minimal social ties, assembling 'the social' within law. In contrast, transitional justice practices create maximal social associations, with the aim of reassembling a society as a whole. This ANT account reveals two fundamental challenges for international justice in transitional contexts. The first is that international criminal justice needs to invent new legal practices that can construct more just legal chains of obligation. This involves the invention of legal practices that include more participants and issues, tie actants together in more equal ways and build more egalitarian assemblages of 'the social' in law. Without undertaking this task of inventing new claims of injustice, fresh forms of adjudication and novel practices of judgement, international criminal law cannot offer new settlements of collective violence. The second task is to construct a relationship between the legal chains of obligation of international criminal law and the chains of social association of transitional justice. This requires extending and multiplying legal chains of obligation through time and space, making them into longer chains of association and connecting these chains to transitional networks that aim to reassemble 'the social.' However, it also requires connecting transitional justice practices to the legal obligations of international criminal justice. This involves the construction of new international legal associations, which can diffract bounded and communitarian (national, ethnic) transitional associations. These new legal obligations can rebuild these nation-state assemblages through the multiplication of new global legal ties. Ultimately, the ICC must meet these challenges of reassembling international justice if it is to extend its networks beyond The Hague. Only then can it fully contribute to reassembling just collectivities in conflict and postconflict transitions.

98 Maria Puig de la Bellacasa, 'Matters of Care in Technoscience: Assembling Neglected Things,' Social Studies of Science 41(1) (2011): 94. 